ISSN: 1576-0162

DOI: http://dx.doi.org/10.33776/rem.v0i59.4903

\title{
Exchange Rate Uncertainty and Cereals Exports: A PANEL VAR APPROACH
}

\author{
INCERTIDUMBRE DEL TIPO DE CAMBIO Y EXPORTACIONES \\ DE CEREALES: UNA APROXIMACIÓN DE PANEL VAR
}

Ronald Miranda Lescano

Institituo de Economía de la Universidad de la República and Departament d'Economia Aplicada de la Universitat Autōnoma de Barcelona ronald.miranda@fcea.edu.uy

Leonel Muinelo Gallo Instituto de Economía de la Universidad de la República leonel.muinelo@fcea.edu.uy

Recibido: julio 2020; aceptado: julio 2021

ABSTRACT

This paper empirically investigates the effect of exchange rate uncertainty on cereals export flows for a broad sample of 75 countries during the 2010/01 - 2016/12 period. To do this, we first estimate the exchange rate volatility, and then, we estimate the cereals export demand by using a panel data model with autoregressive vectors (P-VAR). This strategy of analysis is applied over different groups of countries, which are obtained by cluster analysis based on the level of exchange rate volatility and the volume of cereals exports. The empirical results suggest a significant negative effect of exchange rate uncertainty on cereals exports in countries characterized by high and persistent exchange rate volatility or high volume of cereals exports.

Keywords: Exchange rate uncertainty, cereals exports, panel data, vector autoregressive, cluster analysis.

\section{RESUMEN}

En el presente documento se investiga empíricamente el efecto de la incertidumbre del tipo de cambio en los flujos de exportación de cereales para una amplia muestra de 75 paîses durante el período 2010/01 - 2016/12. Para ello, primero estimamos la volatilidad del tipo de cambio, y luego, estimamos la demanda de exportación de cereales utilizando un modelo de datos de panel con vectores auto-regresivos (P-VAR). Esta estrategia de análisis se aplica a diferentes grupos de países, que se obtienen mediante un análisis de conglomerados basado en el nivel de volatilidad del tipo de cambio y el 
volumen de las exportaciones de cereales. Los resultados empíricos sugieren un efecto negativo de la incertidumbre del tipo de cambio en las exportaciones de cereales en aquellos países caracterizados por una alta y persistente volatilidad del tipo de cambio o un elevado volumen de exportaciones de cereales.

Palabras clave: incertidumbre del tipo de cambio, exportaciones de cereales, datos de panel, vectores auto-regresivos, anâlisis de conglomerados.

Clasificación JEL / JEL Classification: C33, F31, F41. 


\section{INTRODUCTION}

Since the adoption of floating exchange rate regimes in 1973, with the collapse of the fixed exchange rate system adopted at Bretton-Woods, the effect of exchange rate uncertainty on international trade has been relevant for economies (Kandilov, 2008). An extensive literature of theoretical and empirical studies has emerged on this issue. Theoretical works describe the possibility of negative, positive, or neutral impacts of exchange rate uncertainty on international trade. Most of the scholars, however, try to obtain a conclusive empirical result of the effect of exchange rate uncertainty on international trade and generally find a negative impact. Nevertheless, the empirical evidence has not been able to completely support this negative relationship and continues to be a controversial issue in the empirical literature (McKenzie 1999).

This paper empirically analyses the effect of real effective exchange rate volatility, as a proxy of exchange rate uncertainty, on cereals exports for 75 countries during the 2010/01 - 2016/12 period. To do this, we proceed as follows. First, we estimate the real effective exchange rate (REER) volatility using the moving standard deviation of REER (using a 4- and 8-month order of the moving average). Second, we estimate the cereals export demand using panel data models with autoregressive vectors (Abrigo and Love 2016). We also analyse in detail the impulse-response functions. This strategy of analysis is applied over different groups of countries, which are obtained by cluster analysis. On the one hand, we group countries by level of REER volatility. On the other hand, we group countries based on the volume of cereals exports.

Examining cereal exports is essential for at least two important reasons. In the first place, cereals are a crucial source of food in the world, both for human consumption and as inputs in livestock production. Secondly, the entire economy of many developing countries depends to a high degree on the production of only a handful of commodities destined principally for export, which are subject to changing conditions in the world market (e.g. the supply of the main producing and exporting economies). In fact, several scholars (Dawson 2005; Sanjuân-López and Dawson 2010; Kang 2015) support the export-led hypothesis for agricultural exports in developing countries, where export performance is an important determinant of economic growth rate. In this context, exports may contribute to economic growth through various channels: via the foreign trade multiplier, foreign exchange from exports can 
finance imports (e.g. capital goods and technology), and the competition could lead to scale economies, and generate positive externalities (e.g. technological spillovers) (Marin 1992; Dawson 2005; Sanjuán-López and Dawson 2010). ${ }^{1}$ Thus, it is relevant for economic policymakers to understand the effect of macroeconomic variables on cereals exports.

This paper makes a three-fold contribution to the existing literature. First, we provide empirical evidence of the relationship between cereals exports and REER volatility in a large sample of countries. To examine this issue, we analyse and compare different groups of countries. On the one hand, we select high and low REER volatility groups of countries, and on the other hand, we consider high and low volume of cereals exports groups of countries. Second, we make use of a novel high-frequency database from UN Comtrade that is not yet explored in this literature. Thirdly, the dynamics between cereals exports and REER volatility is studied through the use of a novel methodology, specifically, a VAR panel as initially proposed by Love and Zicchino (2006).

The remainder of the paper is organized as follows. Section 2 presents a detailed review of the related economic literature. Data and variables are described in Section 3. The empirical model and methodology are presented in Section 4, while Section 5 presents the main empirical findings. Concluding remarks can be found in Section 6 .

\section{BACKCROUND}

Since the adoption of the floating exchange rate regimes in 1973, a large number of scholars have analysed the impact of exchange rate uncertainty (measures as exchange rate volatility), both nominal and real, on international trade, particularly on exports. However, the theoretical and empirical literature is still not conclusive regarding the sign and magnitude of this impact, having reported negative, positive, neutral and non-significative effects (BahmaniOskooee and Hegerty 2007; Bouoiyour and Selmi 2016; McKenzie 1999).

Traditionally, in the economics literature, it is argued that exchange rate volatility has negative effects on international trade due to its effects on the uncertainty of economic agents regarding the risk of their activities in foreign currency, specifically benefits and costs (Clark 1973; Ethier 1973). Therefore, a major proportion of agents move from more to less risky activities, modifying the economic activities in the economy. Consequently, this change affects the relevant macroeconomic variables of an economy such as the trade balance and the balance of payments, impacting economic growth.

Other scholars, in contrast to the traditional theoretical literature, have expressed that a positive effect of the real exchange rate volatility on international trade can be found. This is due to there being agents that are not risk-averse and perceive the exchange rate volatility as an opportunity

${ }^{1}$ See Giles and Williams 2000a and 2000b for comprehensive surveys. 
to increase their profits (Broll and Eckwert 1999; De Grauwe 1988; Sercu 1992). Sercu (1992) showed that the volatility of exchange rates may increase the volume of trade instead of reducing it. That could happen if high volatility increases the likelihood that the price received by exporters will exceed the costs of trade (e.g. tariffs, transportation). Moreover, De Grauwe (1988) argued that the increase in risk can be decomposed into a substitution effect and an income effect. When the risk increases, the substitution effect operates by reducing export activities in favour of less risky local activities, while the income effect operates in the opposite direction. The decrease in the utility of the expected income from export activities makes it more attractive to invest. Thus, if the income effect outweighs the substitution effect, the increase in foreign exchange risk has a positive effect on export activities. In this sense, Broll and Eckwert (1999) pointed out that which effect dominates will depend on the firm's adjustment to risk. They concluded that volatility can also increase exports, given that an increase in foreign exchange risk will in some cases increase the potential gains of trade.

On the other hand, some researchers suggest there to be insignificant effects because futures markets provide mechanisms to cover against uncertainty in exchange rate movements (Serenis and Tsounis 2013); however, there must be a developed futures market for this to occur (Clark 1973; Ethier 1973).

Many empirical studies have analysed the relationship between exchange volatility and international trade (Bahmani-Oskooee and Hegerty 2007; Coric and Pugh 2010; Ozturk 2006; Selmi and Bouoiyour 2014). For instance, Selmi and Bouoiyour (2014) examined 59 publications from 1984 to 2014. The empirical studies reviewed are distributed by results as follows: 29 negative, 6 positive, 6 not significant and 18 ambiguous. The related meta-analysis, which used the Pearson's correlation coefficient, found that overall effects are generally negative for developing countries, using the real exchange rate, total or sectorial trade, and estimating exchange rate volatility through moving standard deviation. Here, the main problem of the meta-analysis is that results are difficult to compare and generalize because it involves studies that differ in the sample periods, the variables used, the countries considered, the volatility specifications, the aggregation of exports (aggregated, bilateral or sectoral), the exchange rate (nominal, real or effective), methodologies and estimation methods (Bahmani-Oskooee and Hegerty 2007; Ozturk 2006).

Regarding the estimation methodologies used, earlier empirical studies performed simple regressions to evaluate the effects of volatility of exchange rates on exports (Akhtar and Hilton 1984; Cushman 1983; Gotur 1985; Hooper and Kohlhagen 1978). However, the techniques have evolved over time (Bahmani-Oskooee and Hegerty 2007), incorporating Vector Error Correction Models (VECM) (e.g. Arize and Malindretos 1998; Arize 1997; Arize et al 2008; Chowdhury 1993; Kroner and Lastrapes 1993; Miranda and Mordecki 2019) and panel data models (e.g. Hall et al 2010; Sauer and Bohara 2001; Situ 2015; Vilela and MacDonald 2016; Miranda et al 2020). 
Most previous studies analysed the impact of exchange rate uncertainty on export trade, but fewer studies focused on agriculture export trade (Cho et al 2002; Kandilov 2008; Pick 1990). Cho et al (2002) found that exchange rate volatility has a negative impact on agricultural trade for ten developed countries from 1974 to 1995. Kandilov (2008) extended upon the previous work, using a sample of developed, emerging and developing countries from 1975 to 1997 , and reports a larger magnitude of negative effect of exchange rate volatility on agricultural exports in emerging and developing countries than in developed countries. Pick (1990) found that the bilateral U.S. agricultural exports trade with ten economies from 1978 to 1987 was not affected by the exchange rate volatility of the developed countries, but for the group of developing countries the exchange rate volatility adversely affected it.

Despite the potentially crucial effect of exchange rate uncertainty on cereals exports, this impact has not been explored directly in macroeconomic empirical work. Thus, our work attempts to address this gap. Specifically, we examine to what extent exchange rate uncertainty affects the cereals exports for an extended group of countries and by using a Panel VAR methodology.

\section{DATA}

In this section, we present the data used to empirically evaluate the effect of REER volatility on cereals exports. To do this, we construct a panel dataset for a group of 75 countries during the 2010/01 - 2016/12 period, using monthly data. The wide sample of countries allows us to examine this issue from a world trade perspective, involving more than $90 \%$ of the cereals export trade.

The series used correspond to cereals exports 0, world goods imports (), an international commodity prices index disaggregated into non-fuel prices $(0$ and fuel prices 0, and real effective exchange rate (REER) used to calculate the different measures of REER volatility (REERV). The REER for each country is employed because we consider the total cereals exports at the country level. For all cases, the period considered is 2010/01 - 2016/12 (monthly frequency) with a base period of January $2010=100$. Cereals export data are obtained from UN Monthly Comtrade dataset in current US dollars, which we convert into constant prices using the All Commodity Price Index (January $2010=100$ ) from the International Monetary Fund (IMF). ${ }^{2}$ Table 1 describes the categories of cereals. ${ }^{3}$

REER data is obtained from IMF for the sample of selected countries, excluding Peru and Argentina, for which no data was available. For Peru, the information is from ECLAC, and for Argentina, it comes from the International Center of Economics (CEI).

\footnotetext{
2 UN Monthly Comtrade database contains detailed merchandise trade data provided by countries (or geographic regions) to the United Nations Statistics Division, Department of Economic and Social Affairs (UNSD/DESA). https://comtrade.un.org

3 Harmonized Commodity Description and Coding System (HS) is HS 10 https://unstats.un.org/unsd/ tradekb/Knowledgebase/Harmonized-Commodity-Description-and-Coding-Systems-HS.
} 
TABLE 1. CeREALS EXPORTS DESCRIPTION

\begin{tabular}{l} 
Description \\
\hline Cereals \\
Wheat and meslin (durum wheat, meslin and wheat other than durum) \\
Barley \\
Oats \\
Maize (corn, seed and other than seed) \\
Rice (rice in the husk, husked brown rice, semi-milled or wholly milled, whether or not polished or glazed, broken) \\
Grain sorghum \\
Buckwheat, millet and canary seed; other cereals
\end{tabular}

Source: Harmonized Commodity Description and Coding System (HS).

The international literature normally uses Gross Domestic Product (GDP) as a proxy of economies' demand at the country level. However, as world GDP is not available in monthly frequency to approximate the world demand conditions, we use world goods imports in constant dollars (deflated using the United States Consumer Price Index, US CPI), from the IMF. Additionally, we employ the commodity price indices, disaggregated into non-fuel and fuel commodity price indices, from the IMF. Both indices are relevant to explain the export earnings, while the fuel commodity price index is relevant to explain export costs. Table 2 describes the descriptive statistics of the variables.

Finally, it is important to remark that since monthly data being used and the series are not long enough, in this study we applied the X-13ARIMA-SEATS method to seasonally adjust the time series (US Census Bureau 2011 and 2017). 
TABle 2. Descriptive statistics

\begin{tabular}{|c|c|c|c|c|c|c|}
\hline Variable & Variation & Mean & Std. Dev. & Min & $\operatorname{Max}$ & Observations \\
\hline \multirow[t]{3}{*}{$x$} & Overall & 11.272 & 3.296 & -4.761 & 17.239 & $N=5,123$ \\
\hline & Between & & 3.472 & 0.880 & 16.680 & $\mathrm{n}=75$ \\
\hline & Within & & 1.265 & -2.201 & 19.249 & $\mathrm{~T}$-bar $=68.3$ \\
\hline \multirow[t]{3}{*}{ V4 } & Overall & 0.012 & 0.010 & 0.001 & 0.143 & $N=6,000$ \\
\hline & Between & & 0.006 & 0.004 & 0.032 & $\mathrm{n}=75$ \\
\hline & Within & & 0.008 & -0.015 & 0.123 & $T=80$ \\
\hline \multirow[t]{3}{*}{ V8 } & Overall & 0.013 & 0.009 & 0.002 & 0.112 & $N=5,700$ \\
\hline & Between & & 0.007 & 0.004 & 0.035 & $\mathrm{n}=75$ \\
\hline & Within & & 0.007 & -0.015 & 0.090 & $\mathrm{~T}=76$ \\
\hline \multirow[t]{3}{*}{$\mathrm{M}^{*}$} & Overall & 9.517 & 0.041 & 9.397 & 9.571 & $N=$ \\
\hline & Between & &.-- & 9.517 & 9.517 & $\mathrm{n}=$ \\
\hline & Within & & 0.041 & 9.397 & 9.571 & $T=$ \\
\hline \multirow[t]{3}{*}{$P$} & Overall & 4.678 & 0.114 & 4.461 & 4.859 & $N=84$ \\
\hline & Between & & -.- & 4.678 & 4.678 & $\mathrm{n}=1$ \\
\hline & Within & & 0.114 & 4.461 & 4.859 & $T=$ \\
\hline \multirow[t]{3}{*}{$\mathrm{P}^{*}$} & Overall & 4.597 & 0.372 & 3.630 & 5.007 & $N=84$ \\
\hline & Between & & --- & 4.597 & 4.597 & $n=$ \\
\hline & Within & & 0.372 & 3.630 & 5.007 & $\mathrm{~T}=84$ \\
\hline
\end{tabular}

Source: Own estimations.

\subsection{Measure of EXChange Rate unCERTAinty}

Exchange rate uncertainty has been a historically relevant topic in international finance. This concern has recently extended to different areas of the economy, including the preoccupation to understand the dynamics of exchange rates and their impact on different macroeconomic variables (Bollerslev et al 1992).

In this study, we consider a univariate measure of historical volatility to quantify the REERV, quantified as the moving standard deviation (using a 4and 8-month order of the moving average) of the rate of change of REER. ${ }^{4}$

${ }^{4}$ The short sample period avoids using several $m$ horizons to eliminate an arbitrary selection of $m$ (e.g. 12 and 24 periods). 
Specifically, in this paper we adopt the specification of the moving standard deviation used in Chowdhury (1993) and Situ (2015):

$$
V_{t}=\sqrt{\frac{1}{m} \sum_{i=1}^{m}\left[\ln \left(R E E R_{(t+i-1)}\right)-\ln \left(R E E R_{(t+i-2)}\right)\right]^{2}}
$$

where $V$ is the real effective exchange rate volatility, $m$ is the order of moving standard deviation and $t$ denotes time. ${ }^{5}$

This type of measure is considered superior to the second-order moment of the series, since using the latter would not be very useful to capture the variability phenomena for periods of low volatility and periods of high volatility, to calculate an average of the series of the whole period and to determine the variation with respect to the average. In other words, using the moving standard deviation allows the average of the series to vary, and depending on the order of the moving average, it will reflect the volatility sensitivity. The higher the moving average order of the standard deviation, the more difficult to capture variability, and vice versa. For the impact of exchange rate volatility on a macroeconomic variable such as exports, a low order of the measure would a priori be meaningless in the export decision since it is difficult to respond to a phenomenon of very short-term uncertainty. Similarly, a high order of the moving average may not reflect such variability. This is why in this study and according to the literature, we consider the order of the moving standard deviation at $m=4$ and 8 periods.

\subsection{COUNTRY GROUPS}

The aim is to identify groups of units (e.g. countries) that are similar to each other concerning certain characteristics. Cluster analysis is a useful technique for such a purpose. The objective of cluster analysis is to group observations into clusters such that each cluster is as homogeneous as possible with respect to certain characteristics (or clustering variables) and as different from other groups with respect to the same characteristics (Everitt and Dunn 2013).

Cluster analysis implicitly uses a measure of distance as measure of similarity between the units. The more similar the units, the smaller the distance between them and vice versa. Several different similarity measures can be used; however, we have selected the squared Euclidian distance between observed values of a variable for different units of observations as a measure of similarity.

The formula for computing squared Euclidian distance for $p$ variables is given by:

\footnotetext{
${ }^{5}$ Similar procedures for obtaining a measure of exchange rate volatility are presented in Cushman (1983), Ahktar and Hilton (1984), Kenen and Rodrik (1986), Koray and Lastrapes (1989) and Arize (1997).
} 


$$
D_{i j}^{2}=\sum_{k=1}^{p}\left(x_{i k}-x_{j k} k\right)^{2}
$$

where $D_{i j}{ }^{2}$ is the squared distance between country $i$ and $j, x_{i k}$ is the value of the $k$-th variable for the $i$-th unit, $x_{j k}$ is the value of the $k$ th variable for the $j$-th unit and $p$ is the number of variables.

There are two main types of analytical clustering techniques: hierarchical and nonhierarchical. We are limited to considering the first one given that we do not know a priori the number of clusters to be selected.

Hierarchical clustering creates hierarchically related sets of clusters. We use an agglomerative hierarchical clustering method. This method begins with each observation being considered as a separate group ( $N$ groups each of size 1 ; in this case, 75 clusters, one per country). The closest two groups are combined ( $N-1$ groups, one of size 2 and the rest of size 1 ), and this process continues until all observations belong to a group. This process creates a hierarchy of clusters. For computing distance between two clusters, we use the furthest neighbor (i.e. complete linkage) method. This method defines the distance between two clusters as the maximum of the distance between all possible pairs of observations in the two clusters. In general, if cluster $C$ contains units and cluster $\mathbf{S}$ contains units, and then the distance between the two clusters is the maximum of the distance between $n_{c} * n_{s}$ pairs of distances. The following cluster is formed similarly, and the procedure is repeated until all the observations are merged into a cluster.

Thus, we first classify the 75 countries according to the level of homogeneity in moving standard deviation of real effective exchange rates, and second, we classify the 75 countries by volume of cereals exports.

Cluster analysis stopping rules are used to determine how many clusters to select. We used two stopping rules, the Calinski and Harabasz pseudo-F index and the Duda-Hart Je(2)/Je(1) index. Both criteria indicate that the twogroup solution is the most distinct from this hierarchical cluster analysis. The composition of the countries in the two clusters is given in Table 3.

Thus, by classifying the 75 countries based on the level of homogeneity in 4- and 8-period moving standard deviations of real effective exchange rates, we identify two clusters of countries that show low and high REERV, cluster

TABle 3. FREQuenCy of the COUNTRIES BY NUMBer of CLUSTERS

\begin{tabular}{c|c|c|c|c|c|c}
\multirow{2}{*}{ Cluster } & \multicolumn{2}{|c|}{ X } & \multicolumn{2}{c|}{ V4 } & \multicolumn{2}{c}{ V8 } \\
\cline { 2 - 7 } & $\begin{array}{c}\text { Obs. of } \\
\text { countries }\end{array}$ & Frequency & $\begin{array}{c}\text { Obs. of } \\
\text { countries }\end{array}$ & Frequency & $\begin{array}{c}\text { Obs. of } \\
\text { countries }\end{array}$ & Frequency \\
\hline 1 & 29 & $39 \%$ & 64 & $85 \%$ & 57 & $76 \%$ \\
\hline 2 & 46 & $61 \%$ & 11 & $15 \%$ & 18 & $24 \%$ \\
\hline Total & 75 & $100 \%$ & 75 & $100 \%$ & 75 & $100 \%$
\end{tabular}

Source: Own estimations based on UN Comtrade and IMF data. 
1 and cluster 2 respectively. We denoted high REERV as HV and low REERV as $L V$; given that we have 4- and 8-period moving standard deviations of real effective exchange rates, we call them HV4, HV8, LV4 and LV8 respectively (see Figure 1). Meanwhile, we classify the 75 countries by volume of cereals exports, identifying two clusters of countries that are depicted as having low and high volume of cereals exports, cluster 1 and cluster 2 respectively. We denoted high cereals exports as $H X$ and low cereals export as $L X$ (see Figure 2).

Figure 1. CEREALS EXPORTS By HIGH AND LOW REAL EFFECTIVE EXCHANGE RATE VOLATILTY (MEAN PERIOD 2010 - 2016)

a) Moving standard deviation of REER 4-period

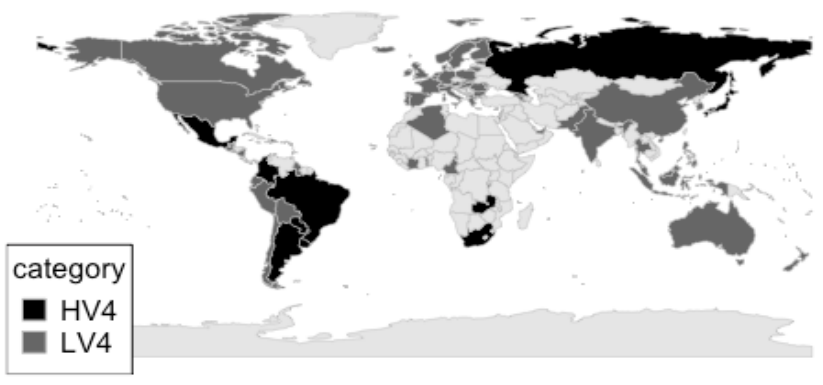

b) Moving standard deviation of REER 8-period

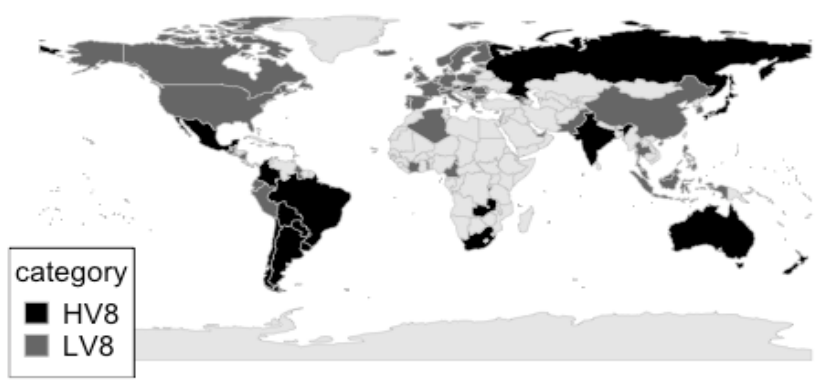

Note: HV4 and LV4 denote the moving standard deviation of real effective exchange rate 4-period, high and low REERV respectively; HV8 and LV8 the moving standard deviation of real effective exchange rate 8-period, high and low REERV respectively.

Source: Own elaboration based on UN Comtrade and IMF data. 
Figure 2. Cereals exports by high and low Cereals exports (MeAn Period 2010 - 2016)

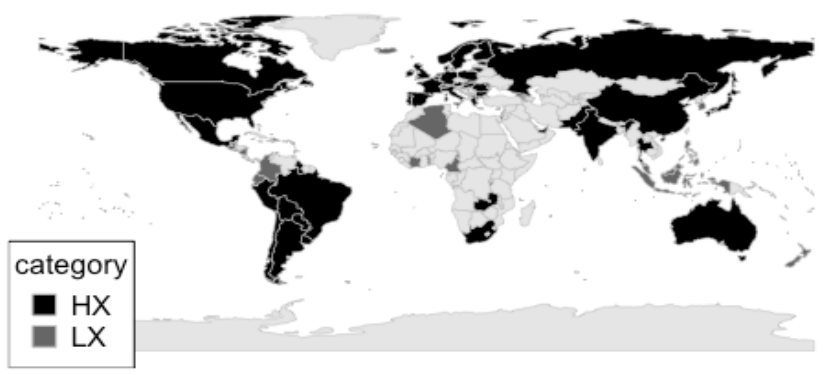

Note: High and low cereals exports, HX and LX respectively.

Source: Own elaboration based on UN Comtrade and IMF data

\section{EMPIRICAL STRATEGY}

In this paper, we propose to estimate the dynamic panel data model with autoregressive vectors using the P-VAR technique with fixed effects developed by Abrigo and Love (2016). ${ }^{6}$ This P-VAR methodology estimates the coefficients using the Generalized Method of Moments with regressor lags as instruments. To guarantee orthogonality between the regressors and the fixed effects, we include the transformation of Helmert (as done by Arellano and Bover 1995 and Love and Zicchino 2006).

Once the P-VAR models have been estimated in their reduced form, simulation exercises can be performed through calculation of impulse-response functions to determine and compare the magnitude, significance and sign of a single and "unexpected" orthogonal shock of one variable over another. Also, the decomposition of the variance of the predicted error can be examined in order to determine the cumulative relative contribution of the shock on the variable of interest.

A common specification of the export equation is (Arize and Malindretos 1998; Arize 1997; Arize et al 2008; Chowdhury 1993; Miranda 2020; Bayar 2018 for a survey)

$$
X_{i t}=\alpha_{1} X_{i t-p}+\alpha_{2} P_{i t-p}+\alpha_{3} R E E R V_{i t-p}+\beta_{1} M_{i t}^{*}+\beta_{2} P_{i t}^{*}+U_{i}+e_{i t}
$$

with $p$ lags, where represents the country and $t$ is the time period between $2010 / 01$ and 2016/12. The endogenous variables of the model are cereals exports $(X)$, the non-fuel commodity price index $(P)$ and the measures of REERV. The exogenous variables of the model are world goods imports $\left(M^{*}\right)$ and the fuel commodity price index $\left(P^{*}\right) . v_{t}$ represents the fixed-effects variable that captures unobservable individual heterogeneity and $e_{i t}$ contains the

${ }^{6}$ Abrigo and Love (2016) provide an available STATA code for the use of researchers. https://sites. google.com/a/hawaii.edu/inessalove/home/pvar 
idiosyncratic errors. The coefficients $\alpha_{1}, \alpha_{2}, \alpha_{3}, \beta_{1}$ and $\beta_{2}$ are the parameters to be estimated. Here, we specify a panel model with fixed effects, which captures the specific components of each country that are invariant over time and that affect the variables to be explained (for instance: trade liberalization, level of development of financial markets, country size, production structure). Note that the P-VAR with fixed-effects estimates averages effects of heterogeneous groups of the unit of analysis -in this case, the country unit- to characterize the country-specific differences relative to the overall average (Canova and Ciccarelli 2013).

\section{EMPIRICAL ResultS}

In this section, we proceed as follows. First, we present the panels' estimation results by high and low REERV. Then we report the estimations for the panels by high and low levels of cereals exports. Second, we show the postestimations outcomes. ${ }^{7}$

\subsection{HiGH AND LOW REAL EFFECTIVE EXCHANGE RATE VOLATILITY}

Table 4 reports the P-VAR estimation results of Equation 3 for the entire sample of countries (models 1 to 2) and for countries characterized by the high and low levels of REERV using the two different specifications of it (models 3 to 6). The main findings of models 1 to 6 can be summarized as follows. Regarding endogenous variables, first, the cereals export variable lag is positive and significant at $1 \%$ level. In other words, past changes in exports are relevant in explaining contemporary exports. Second, the non-fuel commodity price index is positive and insignificant, except for model 6 where it is negative and significant at $5 \%$. The positive signs on the non-fuel commodity price index mean that the increase in prices encourages producers to increase cereals exports. The negative sign, however, could be associated with the fact that cereals exports have historically been restricted by trade policy. For instance, a cereals export tax reduces the volume of international trade of cereals by increasing the cost of exports, i.e. raising the market price of exports (Estrades et al 2017)in a global context of rising food prices, many countries applied priceisolating policies. Export restrictions were among the measures most frequently applied. However, as countries are not obliged to notify WTO about the imposition of export restrictions, there is not good information about the measures applied. We fill this void by building a comprehensive database on export restrictions applied in the agricultural sector worldwide between

${ }^{7}$ Table A.2 and Table A.3 present the main results of the unit root test for the panels of countries for the entire 2010/01-2016/12 period. 
2005 and 2014. We name it the Export Restriction in Agriculture (ERA. Third, the REERV is negative from models 1 to 6 , although it is only significant (at $10 \%$ level) in the case of model 6 . This result is associated with risk-averse agents among those involved in international trade of cereals exports. However, exchange rate uncertainty is relevant to explain cereals exports in countries characterised by high 8-period REERV. Note that cereals export contract includes requirements of quantity, price per unit, payment terms, etc. Therefore, exchange rate fluctuations have negligible effects on the volume of cereals exports in the short term (Grier and Smallwood 2007)while it has an insignificant effect for a majority of the developed countries. In both groups, foreign income uncertainty has a more pervasively significant (and frequently larger.

Regarding exogenous variables, first, the global demand conditions positively impacted on variation in cereals exports; the results are statistically insignificant in models 1 to 5 and significant at the $1 \%$ level in the case of model 6 . Second, the fuel commodity price index represents an important share of the production and transportation costs for cereals exports, explaining the negative and significant coefficient from models 1 to 5 (but not for model 6).

TABLE 4. Estimation RESUltS BY HIGH/LOW REeRV

\begin{tabular}{c|c|c|c|c|c|c}
\multirow{2}{*}{ Equation: X } & V4 & V8 & LV4 & HV4 & LV8 & HV8 \\
\cline { 2 - 6 } & $(1)$ & $(2)$ & $(3)$ & $(4)$ & $(5)$ & $(6)$ \\
\hline \multirow{2}{*}{ L.X } & $0.341 * * *$ & $0.351^{* * *}$ & $0.336^{* * *}$ & $0.429 * * *$ & $0.366^{* * *}$ & $0.301^{* * *}$ \\
\cline { 2 - 7 } & $(0.050)$ & $(0.049)$ & $(0.052)$ & $(0.104)$ & $(0.057)$ & $(0.078)$ \\
\hline \multirow{2}{*}{ L.P } & 0.109 & 0.081 & 0.113 & 0.051 & 0.415 & $-1.054^{* *}$ \\
\cline { 2 - 7 } & $(0.247)$ & $(0.263)$ & $(0.279)$ & $(0.419)$ & $(0.314)$ & $(0.469)$ \\
\hline \multirow{2}{*}{ L.REERV } & -1.878 & -4.088 & -1.179 & -0.231 & -4.096 & $-4.285^{*}$ \\
\cline { 2 - 7 } & $(2.032)$ & $(2.618)$ & $(3.738)$ & $(1.872)$ & $(5.899)$ & $(2.214)$ \\
\hline \multirow{2}{*}{ M* } & 1.520 & 1.704 & 1.466 & 1.752 & 0.060 & $7.193^{* * *}$ \\
\cline { 2 - 7 } & $(1.099)$ & $(1.373)$ & $(1.258)$ & $(0.279)$ & $(1.828)$ & $(2.068)$ \\
\hline \multirow{2}{*}{ P* } & $-0.337 * *$ & $-0.346 * * *$ & $-0.328 * *$ & $-0.339 *$ & $-0.433 * * *$ & -0.058 \\
\cline { 2 - 7 } & $(0.127)$ & $(0.134)$ & $(0.146)$ & $(0.051)$ & $(1.828)$ & $(0.274)$ \\
\hline No. of Obs. & 3689 & 3478 & 3,196 & 493 & 2.638 & 840 \\
\hline No. of panels & 70 & 70 & 61 & 9 & 55 & 15 \\
\hline Ave. no. of T & 52.700 & 49.686 & 52.393 & 54.778 & 47.964 & 56
\end{tabular}

Note: We considered the first difference of the logarithm of the variable (seasonal adjusted). Level of significance: ${ }^{*}: 10 \%, * *: 5 \%, * * *: 1 \%$. Equation $3-6$ uses the (high and low) REERV calculated through the moving standard deviation 4- and 8-period respectively.

Source: Own elaboration based on UN Comtrade and IMF data. 


\subsection{HiGH AND LOW VOLUME OF CEREALS EXPORTS}

Table 5 shows the estimates of the entire panel (models 1 and 2, similarly to model 1 and 2 of Table 4) and of the high and low volume cereals export panels for the two measures of the REERV (models 3 to 6). In all models, the lags of the endogenous variables, such as exports, are significant at $1 \%$. Moreover, the non-fuel commodity price index was significant at 5\% in models $3-6$, in this case with an observed negative impact on cereals exports. While the effect of non-fuel commodity prices on cereals exports is negative among high volume cereals exporters (i.e. with market power in global markets) because exports restrictions increase the cost of producing exported goods and thus higher export prices reduce export volume, this upward influence on international trading prices (due to lower volumes) attracts additional production, which may explain the positive sign on the non-fuel commodity index among low volume cereals exporters (with small influence on global market) (Estrades et al 2017)in a global context of rising food prices, many countries applied priceisolating policies. Export restrictions were among the measures most frequently applied. However, as countries are not obliged to notify WTO about the imposition of export restrictions, there is not good information about the measures applied. We fill this void by building a comprehensive database on export restrictions applied in the agricultural sector worldwide between 2005 and 2014. We name it the Export Restriction in Agriculture (ERA. An alternative explanation emerges from the global supply chain's view. When country exports are expensive in relative terms, domestic exporters could reduce the production costs by demanding inputs from the world markets, making their goods more competitive and stimulating the demand for them. Accordingly, depending on the country and which channel dominates, the impact of relative prices could be positive or negative on exports (see Bems and Johnson 2017 for a comprehensive explanation). The REERV was significant at 5\% when we use the 8-period moving standard deviation of countries characterized by high cereals exports (model 6), and the impact is negative. In other cases, REERV is not significant. These results are consistent with the empirical evidence of a negative or insignificant effect (Miranda and Mordecki 2019; Situ 2015; Vilela and MacDonald 2016). Thus, our finding provides a result not present in previous studies, specifically; that countries with market power in cereals exports are risk-averse under exchange rate uncertainty.

On the other hand, regarding the exogenous variable, the coefficient on the fuel commodity price index is negative in all models (1 to 6), and is significant in models 1, 2, 4 and 6. Specifically, an increase in it causes a reduction in the cereals exports in countries classified as having high cereals exports. One possible reason is because cereals production is highly fuel-dependent, and fuels represent a factor cost in food production and distribution. In particular, modern agriculture on seed fertilizer technology is based on chemical inputs derived from oil (Avalos 2014). The global demand 
TABLE 5. ESTIMATION RESULTS BY HIGH/LOW CEREALS EXPORTS

\begin{tabular}{|c|c|c|c|c|c|c|}
\hline \multirow{2}{*}{ Equation: $X$} & $X-V 4$ & $X-V 8$ & LX-V4 & $\mathrm{HX}-\mathrm{V} 4$ & LX-V8 & HX-V8 \\
\hline & (1) & (2) & (3) & (4) & (5) & (6) \\
\hline \multirow{2}{*}{ L.X } & $0.341 * * *$ & $0.351^{* * *}$ & $0.264^{* * *}$ & $0.512 * * *$ & $0.281 * * *$ & $0.499 * * *$ \\
\hline & $(0.050)$ & $(0.049)$ & $(0.066)$ & $(0.048)$ & $(0.065)$ & $(0.046)$ \\
\hline \multirow{2}{*}{ L.P } & 0.109 & 0.081 & $1.928^{* *}$ & $-0.388 * *$ & $1.801^{* *}$ & $-0.399 * *$ \\
\hline & $(0.247)$ & $(0.263)$ & $(0.812)$ & $(0.168)$ & $(0.876)$ & $(0.178)$ \\
\hline \multirow{2}{*}{ L.REERV } & -1.878 & -4.088 & 4.394 & -2.359 & -0.647 & $-3.932 * *$ \\
\hline & $(2.032)$ & (2.618) & (7.771) & (1.518) & (9.323) & (1.929) \\
\hline \multirow{2}{*}{$M^{*}$} & 1.520 & 1.704 & $-15.858 * * *$ & $5.579 * * *$ & $-15.375^{* * *}$ & $5.839 * * *$ \\
\hline & $(1.099)$ & (1.373) & $(3.747)$ & $(0.874)$ & $(4.712)$ & $(1.093)$ \\
\hline \multirow{2}{*}{$\mathrm{P}^{*}$} & $-0.337^{* * *}$ & $-0.346^{* * *}$ & -0.222 & $-0.254^{* * *}$ & -0.110 & $-0.303^{* * *}$ \\
\hline & $(0.127)$ & $(0.134)$ & $(0.406)$ & $(0.094)$ & $(0.441)$ & $(0.101)$ \\
\hline No. of Obs. & 3689 & 3478 & 977 & 2,712 & 919 & 2,559 \\
\hline No. of panels & 70 & 70 & 24 & 46 & 24 & 46 \\
\hline Ave. no. of T & 52.700 & 49.686 & 40.708 & 58.957 & 38.292 & 55.630 \\
\hline
\end{tabular}

Note: We considered the first difference of the logarithm of the variable (seasonal adjusted). Level of significance: ${ }^{*}: 10 \%,{ }^{* *}: 5 \%,{ }^{* * *}: 1 \%$. Equation $3-6$ uses the volume of cereals exports (low exports - LX- and high exports -HX-) by the moving standard deviation 4- and 8-period respectively.

Source: Own elaboration based on UN Comtrade and IMF data.

conditions have an effect that is positive in countries with high cereals exports and negative in countries with low cereals exports, both significant at $1 \%$; the negative sign is probably explained by the economic context - slow global demand growth and a decrease in the commodities prices in this period of analysis may not affect countries with low cereals export volume.

\section{Post-estimation tests}

\subsection{GRANGer TEST}

The presence of correlation between two variables does not always imply causality (where changes in one of them determine the changes in the values of the other). Therefore, the Granger causality test (Granger 1969) is carried out. Rejecting the null hypothesis, in this case, would imply that past changes in one variable affect or precede the other variable, in which case it would not be exogenous. Table 6 shows the results of the Granger causality test for the high and low REERV and high and low volume of cereals exports; they are reported for REERV and cereals exports.

Firstly, we find a significant relationship between 8-period moving standard deviation of REER and high volumes of cereals exports. And the direction of 
TABle 6. Granger causality test (WALd)

Ho: Excluded variable does not Granger-cause Equation variable

Ha: Excluded variable Granger-cause Equation variable

\begin{tabular}{|c|c|c|c|c|c|}
\hline Equation & Excluded & Chi2 & Equation & Excluded & Chi2 \\
\hline$x$ & LV4 & 0.100 & $L X$ & V4 & 0.320 \\
\hline LV4 & $x$ & 0.146 & V4 & $L X$ & 0.085 \\
\hline$x$ & HV4 & 1.523 & $H X$ & V4 & 2.416 \\
\hline HV4 & $x$ & 0.063 & V4 & $H X$ & 0.006 \\
\hline$x$ & LV8 & 0.482 & $L X$ & V8 & 0.005 \\
\hline LV8 & $x$ & 0.261 & V8 & LX & 0.000 \\
\hline$x$ & HV8 & $3.747^{*}$ & $H X$ & V8 & $4.156^{* *}$ \\
\hline HV8 & $x$ & $3.096^{*}$ & v8 & $H X$ & 2.606 \\
\hline
\end{tabular}

Notes: Rejection of the null hypothesis: ${ }^{*}: 10 \%,{ }^{* *}: 5 \%$ and ${ }^{* * *}: 1 \%$ of significance (Prob. > Chi2). Sample: 2010/01 - 2016/12. The variables were considered in logarithm. Results are reported for cereals exports and the different measures of volatility by high and low REERV (HV and LV, respectively) and by high and low volume of cereals exports (HX and LX, respectively). V4 and V8 refer to the moving standard deviation 4- and 8-period respectively.

Source: Own estimations based on UN Comtrade and IMF data.

causation is from 8-period moving standard deviation of REER to high volumes of cereals exports (i.e., unidirectional Granger causality). Secondly, we can observe a significant link between exports and 8-period moving standard deviation of REERV. Yet, in this case, the direction of causality is not conclusive (i.e., bidirectional Granger causality).

\subsection{IMPULSE-RESPONSE FUNCTIONS}

Here, we discuss the simulation of impulse-response functions (IRFs). The focus of the analysis is to quantify effects of macroeconomics shocks one at a time to see how they affect cereals exports, with particular interest in the impact of an exchange rate volatility shock. In the IRF graphs, the cereals export responses are caused by an orthogonal impulse or shock, one standard deviation in magnitude, to the non-fuel commodity price index and the REERV measures. The export response is considered on a monthly basis for a period of 18 months. Here, we assume the following recursive order to construct the IRF:

$$
P \rightarrow V \rightarrow X
$$


The economic intuition of this Cholesky order can be expressed as follows: first, the non-fuel commodity price index is the most important variable for the panels, based on its effect on the terms of trade and thus on the decision of the exporters of different countries to export. Specifically, if there is an increase in the relative prices of exports, then the country's export goods become more expensive in the world markets; this leads to decreased competitiveness and thus a decline in the export supply's decision (Bayar 2018). Second, due to the effect of uncertainty on cereals exports, the impact of exchange rate volatility cannot be accurately predicted. Given that exports are presumed to respond at the same time as the rest of the system variables, this variable is in the last position in Cholesky's order (Gevorkyan 2019).

Following the results identified in subsections 5.1 and 5.2, Figure 3 illustrates the IRF of the endogenous variables of two selected specifications: a) countries characterized by high 8-period REERV (HV8), see model 6 in Table 4 and b) countries characterized by high volume of cereals exports and 8-period REERV (HX-V8), see model 6 in Table 5.

Focusing on subfigure a) of Figure 3, firstly, a one standard deviation shock of non-fuel commodity price index has a negative and significant impact on cereals exports. The estimated magnitude suggests that a one standard deviations shock to the non-fuel commodity price index translates to about $5 \%$ decline in cereals exports - the maximum impact is in period three. This expected response is in line with theoretical priors: an increase in non-fuel commodity prices index reduces the global markets demand for cereals exports. Secondly, the response of cereals exports to a one standard deviation shock of high 8-period REERV is statistically insignificant at 95\% (i.e. the 95 confidence band is into the zero line).

Turning now to subfigure b) of Figure 3, we observe that cereals exports react negatively and significantly to non-fuel commodity prices index. Also, a one standard deviation shock to non-fuel commodity prices index results in about $0.3 \%$ decrease in cereal - the maximum impact is in period four. A shock to the 8-period REERV in countries characterized by high cereals exports has an insignificant effect on cereals exports.

For both subfigures a) and b) of Figure 3, the response of cereals exports to itself is immediately positive and strongly significant, a magnitude about $0.8 \%$ at the time of the shock, and then turns rapidly to zero.

To summarize the results, while the REERV variable's impulse does not induce a significant export response in the short- and medium-term, the nonfuel commodity price index is negative and significant, see subfigures a) and b).

In addition, the P-VAR methodology allows an IRF to simulate a shock to the exogenous variable and its effect on the endogenous variables of interest. The results are illustrated in Figure 4. In the case of subfigure a), we observe that a one standard deviation unit shock to the fuel commodity prices index has an insignificant impact on cereals exports (i.e., the 95 confidence band is into the zero line). However, in the case of countries characterized by high cereals exports, see subfigure b), cereals exports respond to 
FIGURE 3. IMPULSE-RESPONSE FUNCTION: ENDOGENOUS VARIABLES

a) Countries characterized by HV8
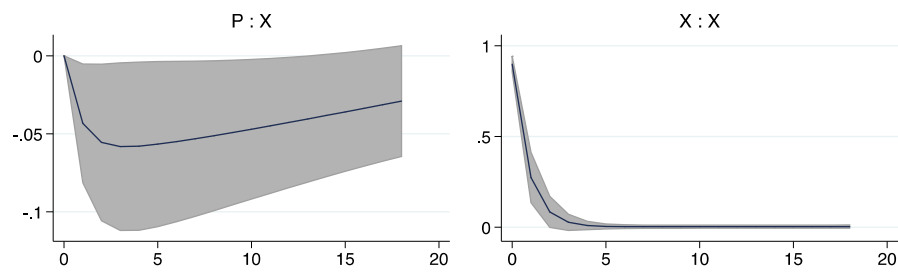

HV8 : X

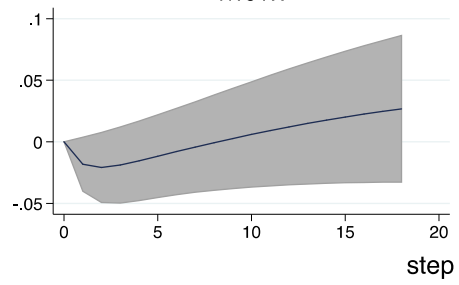

$95 \% \mathrm{Cl} \longrightarrow$ Orthogonalized IRF

impulse : response

b) Countries characterized by HX-V8
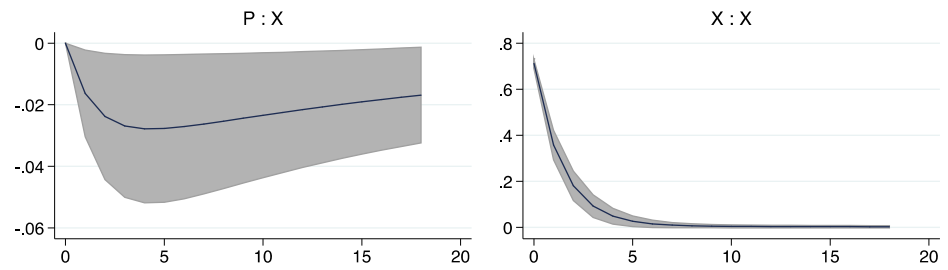

$H X-V 8: X$

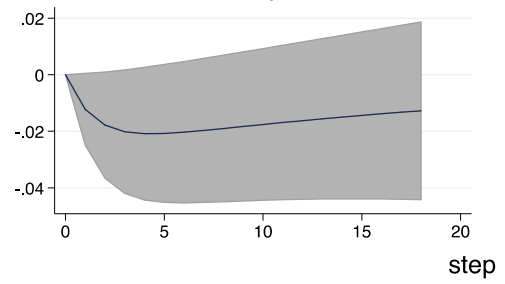

$95 \% \mathrm{Cl}$

Orthogonalized IRF

impulse : response

Note: Impulse (endogenous variable) : response (cereals export). The band containing the IRF corresponds to $95 \%$ confidence.

Source: Own estimations based on UN Comtrade and IMF data. 
one standard deviation unit shock of fuel commodity prices index is negative and significant (a magnitude close to $0.3 \%$ ). As we expected, for both subfigures a) and b) of Figure 4, we observe that a unit shock to global demand results in about $7 \%$ and $6 \%$ increases of cereals exports, respectively.

\section{Conclusions}

This paper examines the relationship between exchange rate uncertainty and cereals exports for a large panel of developed and developing countries over 2010/01 - 2016/12, using a P-VAR methodology. Although the empirical literature on this issue is extensive, to our knowledge no previous studies examine the links between exchange rate uncertainty and cereals exports. Specifically, we focus on knowing the impact of real exchange rate volatility on cereals exports over different groups of countries, which are obtained by cluster analysis based on the level of real effective exchange rate volatility and the volume of cereals exports.

Our empirical findings suggest the following conclusions. First, exchange rate uncertainty is important for modeling cereals exports in countries with high exchange rate volatility and high cereals export volume (i.e. with market power), with the 8-period REERV having the best results with our methods. The economic interpretation of the negative impact of REERV on cereals exports appears to be associated with the "average" exporting country that display risk-averse behavior or has some contract flexibility to adjust their exports in the medium-term. Second, this paper also reports evidence of the link between cereals exports and other macroeconomic variables. While the impact of non-fuel commodity price index on cereal exports is associated with export restrictions as well as the global supply chains, the fuel commodity price index represents an export cost for countries. Furthermore, global demand conditions are among the most important factors explaining variations in cereals exports. Note that if the foreign income improves, it may encourage more imports and thus boosts demand for exported goods. Therefore, the total cereals exports show a positive income effect in our sample of countries. Eventually, this finding may vary according to the type of cereal that countries export.

Thus, this empirical analysis leads us to suggest policymakers mitigate exchange rate fluctuations to reduce the risk associated with cereals export activity, and consequently, to stabilize the external trade position, specifically in countries that can influence the cereals export markets. In this sense, it is relevant to note that using the same policies would likely have divergent effects according to the cluster of countries examined. 
FIGURE 4. IMPULSE-RESPONSE FUNCTION: EXOGENOUS VARIABLES

a) Countries characterized by HV8
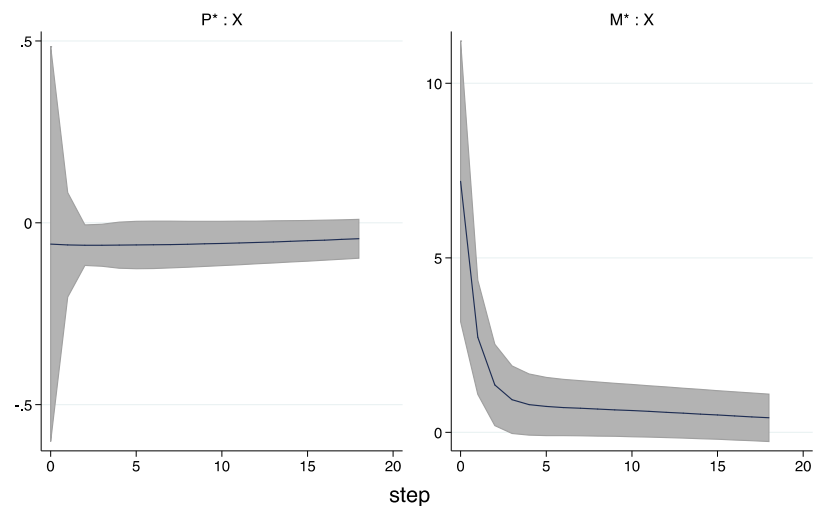

$95 \% \mathrm{Cl} \longrightarrow$ Dynamic Multipliers

impulse : response

b) Countries characterized by $\mathrm{HX}-\mathrm{V} 8$
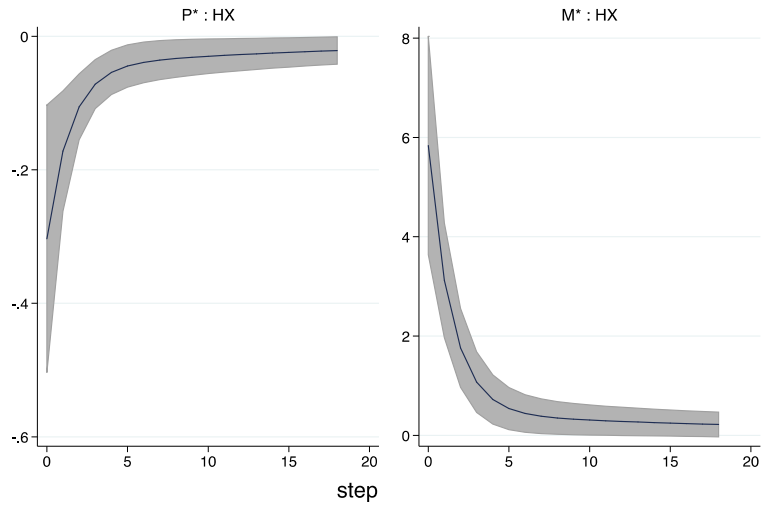

$95 \% \mathrm{Cl}$

Dynamic Multipliers

impulse : response

Note: Impulse (endogenous variable) : response (cereals export). The band containing the IRF corresponds to $95 \%$ confidence.

Source: Own estimations based on UN Comtrade and IMF data. 


\section{REFERENCES}

Avalos, F. (2014). Do Oil Prices Drive Food Prices? The Tale of a Structural Break. Journal of International Money and Finance, 42, 253-271. https:// doi.org/10.1016/j.jimonfin.2013.08.014

Abrigo, M., \& Love, I. (2016). Estimation of Panel Vector Autoregression in STATA: a package of programs (Working paper 201602; 1-28). University of Hawaii. http://paneldataconference2015.ceu.hu/Program/Michael-Abrigo. pdf

Akhtar, M. A., \& Hilton, R. S. (1984). Effects of Exchange Rate Uncertainty on German and U.S. Trade. Federal Reserve Bank of New York Quarterly Review, 9, 7-16.

Arellano, M., \& Bover, O. (1995). Another Look at the Instrumental Variable Estimation of Error-Components Models. Journal of Econometrics, 68(1), 29-51. https://doi.org/10.1016/0304-4076(94)01642-D

Arize, A. C., \& Malindretos, J. (1998). The Long-Run and Short-Run Effects of Exchange-Rate Volatility on Exports: The Case of Australia and New Zealand. Journal of Economics and Finance, 22(2), 43-56. https://doi. org/10.1007/BF02771475

Arize, Augustine C. (1997). Conditional Exchange-Rate Volatility and the Volume of Foreign Trade: Evidence from Seven Industrialized Countries. Southern Economic Journal, 64(1), 235-254. JSTOR. https://doi. org/10.2307/1061049

Arize, Augustine C., Osang, T., \& Slottje, D. J. (2008). Exchange-Rate Volatility in Latin America and its Impact on Foreign Trade. International Review of Economics \& Finance, 17(1), 33-44. https://doi.org/10.1016/j. iref.2006.01.004

Bahmani-Oskooee, M., \& Hegerty, S. W. (2007). Exchange Rate Volatility and Trade Flows: A Review Article. Journal of Economic Studies, 34(3), 211 255. https://doi.org/10.1108/01443580710772777

Bayar, G. (2018). Estimating Export Equations: A Survey of the Literature. Empirical Economics, 54(2), 629-672. https://doi.org/10.1007/s00181-0161220-3

Bems, R., \& Johnson, R. C. 2017. Demand for Value Added and Value-Added Exchange Rates. American Economic Journal: Macroeconomics, 9(4), 4590. https://doi.org/10.1257/mac.20150216

Bouoiyour, J., \& Selmi, R. (2016). A Synthesis of the Effects of Exchange Rate Volatility on International Trade: A Meta-Regression Analysis. International Trade Journal, 30(4), 263. https://doi.org/10.1080/08853908.2016.119 4789

Broll, U., \& Eckwert, B. (1999). Exchange Rate Volatility and International Trade. Southern Economic Journal, 66(1), 178-185. https://doi. org/10.2307/1060843

Canova, F., \& Ciccarelli, M. (2013). Panel Vector Autoregressive Models: A Survey. In VAR Models in Macroeconomics-New Development and Appli- 
cations: Essays in Honor of Christopher A. Sims (Vol. 32, pp. 205-246). Emerald Group Publishing Limited.

Census Bureau US. (2011). X-12-ARIMA Reference Manual, Version 0.3 (pp. 1-249). https://www.census.gov/ts/x12a/v03/x12adocV03.pdf

Census Bureau US. (2017). X-13ARIMA-SEATS Reference Manual, Version 1. 1. http://www.census.gov/srd/www/x13as/

Cho, G., Sheldon, I. M., \& McCorriston, S. (2002). Exchange Rate Uncertainty and Agricultural Trade. American Journal of Agricultural Economics, 84(4), 931-942. https://doi.org/10.1111/1467-8276.00044

Chowdhury, A. (1993). Does Exchange Rate Variability Depress Trade Flows? Evidence from Error Correction Models. The Review of Economics and Statistics, 75(4), 700-706. https://doi.org/10.2307/2110025

Clark, P. B. (1973). Uncertainty, Exchange Risk, and the Level of International Trade. Economic Inquiry, 11 (3), 302. https://doi.org/10.1111/j.1465-7295.1973. tb01063.x

Coric, B., \& Pugh, G. (2010). The Effects of Exchange Rate Variability on International Trade: A Meta-Regression Analysis. Applied Economics, 42(20), 2631-2644. https://doi.org/10.1080/00036840801964500

Cushman, D. o. (1983). The Effects of Real Exchange Rate Risk on International Trade. Journal of International Economics, 15(1-2), 45-63. https:// doi.org/10.1016/0022-1996(83)90041-7

Dawson, P. J. (2005) Agricultural Exports and Economic Growth in Less Developed Countries. Agricultural Economics, 33, 145-152. https://doi. org/10.1111/j.1574-0862.2005.00358.x

De Grauwe, P. (1988). Exchange Rate Variability and the Slowdown in Growth of International Trade. Staff Papers (International Monetary Fund), 35(1), 63-84. https://doi.org/10.2307/3867277

Estrades, C., Flores, M., \& Lezama, G. (2017). The Role of Export Restrictions in Agricultural Trade (p. 53). International Agricultural Trade Research Consortium.

Ethier, W. (1973). International Trade and the Forward Exchange Market. The American Economic Review, 63(3), 494-503.

Everitt, B. S., \& Dunn, G. (2013). Cluster Analysis. In Applied Multivariate Data Analysis (pp. 125-160). John Wiley \& Sons, Ltd. https://doi. org/10.1002/9781118887486.ch6

Gevorkyan, A. V. (2019). Exchange Market Pressure and Primary Commodity - Exporting Emerging Markets. Applied Economics, 51 (22), 2390-2412, https://doi.org/10.1080/00036846.2018.1545077

Giles, J. A. \& Williams, C. L. (2000a). Export-Led Growth: A Survey of the Empirical Literature and Some Non-Causality Results. Part 1. Journal of International Trade and Economic Development, 9, 261-337. https://doi. org/10.1080/09638190050086177

Giles, J. A. \& Williams, C. L. (2000b). Export-Led Growth: A Survey of the Empirical Literature and Some Non-Causality Results. Part 2. Journal of 
International Trade and Economic Development, 9, 445-470. https://doi. org/10.1080/096381900750056867

Gotur, P. (1985). Effects of Exchange Rate Volatility on Trade: Some Further Evidence. IMF Economic Review, 32(3), 475-512. https://doi. org/10.2307/3866807

Granger, C. (1969). Investigating Causal Relations by Econometric Models and Cross-Spectral Methods. Econometrica, 37(3), 424-438. https://doi. org/10.2307/1912791

Grier, K. B., \& Smallwood, A. D. (2007). Uncertainty and Export Performance: Evidence from 18 Countries. Journal of Money, Credit and Banking, 39(4), 965-979. https://doi.org/10.1111/j.1538-4616.2007.00053.x

Hall, S., Hondroyiannis, G., Swamy, P. A. V. B., Tavlas, G., \& Ulan, M. (2010). Exchange-Rate Volatility and Export Performance: Do Emerging Market Economies Resemble Industrial Countries or Other Developing Countries? Economic Modelling, 27(6), 1514-1521. https://doi.org/10.1016/j.econmod.2010.01.014

Hooper, P., \& Kohlhagen, S. (1978). The Effect of Exchange Rate Uncertainty on the Prices and Volume of International Trade. Journal of International Economics, 8(4), 483-511. https://doi.org/10.1016/0022-1996(87)90001-8

Kandilov, I. T. (2008). The Effects of Exchange Rate Volatility on Agricultural Trade. American Journal of Agricultural Economics, 90(4), 1028-1043. https://doi.org/10.1111/j.1467-8276.2008.01167.x

Kang, H. (2015). Agricultural Exports and Economic Growth: Empirical Evidence from the Major Rice Exporting Countries. Agriculture Economics, 61 , 81-87. https://doi.org/10.17221/99/2014-AGRICECON

Kroner, K. F., \& Lastrapes, W. D. (1993). The Impact of Exchange Rate Volatility on International Trade: Reduced form Estimates Using the GARCH-in-Mean Model. Journal of International Money and Finance, 12(3), 298-318. https://doi.org/10.1016/0261-5606(93)90016-5

Love, I., \& Zicchino, L. (2006). Financial Development and Dynamic Investment Behavior: Evidence from Panel VAR. The Quarterly Review of Economics and Finance, 46(2), 190-210. https://doi.org/10.1016/j.qref.2005.11.007

Marin, D. (1992). Is the Export-Led Growth Hypothesis Valid for Industrialized Countries? The Review of Economics and Statistics, 74(4), 678-688. doi: 10.2307/2109382

McKenzie, M. D. (1999). The Impact of Exchange Rate Volatility on International Trade Flows. Journal of Economic Surveys, 13(1), 71-106. https:// doi.org/10.1111/1467-6419.00075

Miranda, R., \& Mordecki, G. (2019). Real Exchange Rate Volatility and Exports: A Study for Four Selected Commodity Exporting Countries. Panoeconomicus, 66(4), 411-437. https://doi.org/10.2298/PAN160927010M

Miranda, R., Mordecki, G. \& Muinelo, L. (2020). The Impact of Exchange Rate Uncertainty on Exports: A Panel VAR Analysis. Estudios de Economia, 47(2), 157-192. 
Ozturk, I. (2006). Exchange Rate Volatility and Trade: A Literature Survey. International Journal of Applied Econometrics and Quantitative Studies, 3(1), 85-102.

Pick, D. H. (1990). Exchange Rate Risk and U.S. Agricultural Trade Flows. American Journal of Agricultural Economics, 72(3), 694-700. JSTOR. https://doi.org/10.2307/1243039

Sanjuān-López, A. I. \& Dawson P. J. (2010). Agricultural Exports and Economic Growth in Developing Countries: A Panel Cointegration Approach. Journal of Agricultural Economics, 61, 565-583. https://doi.org/10.1111/j.14779552.2010.00257.x

Sauer, C., \& Bohara, A. K. (2001). Exchange Rate Volatility and Exports: Regional Differences between Developing and Industrialized Countries. Review of International Economics, 9(1), 133-152. https://doi.org/10.1111/14679396.00269

Selmi, R., \& Bouoiyour, J. (2014). How Does Exchange Rate Uncertainty Interact with International Trade? A Meta-Analysis Revisited. MPRA Paper. https://mpra.ub.uni-muenchen.de/56419/

Sercu, P. (1992). Exchange Risk, Exposure, and the Option to Trade. Journal of International Money and Finance, 11(6), 579-593. https://doi. org/10.1016/0261-5606(92)90005-I

Serenis, D., \& Tsounis, N. (2013). Exchange Rate Volatility and Foreign Trade: The Case for Cyprus and Croatia. Procedia Economics and Finance, 5, 677-685. https://doi.org/10.1016/S2212-5671(13)00079-8

Situ, J. (2015). The Impact of Real Exchange Rate Volatility on Exports to U.S.: A Comparison between Developed and Export-Oriented Less Developed Countries. International Journal of Business and Management, 10(5), $214-$ 221. https://doi.org/10.5539/ijbm.v10n5p214

Vilela, F., \& MacDonald, R. (2016). Exchange Rate Volatility and Exports: A Panel Data Analysis. Journal of Economic Studies, 43(2), 203-221. https:// doi.org/10.1108/JES-05-2014-0083 
APPENDIX

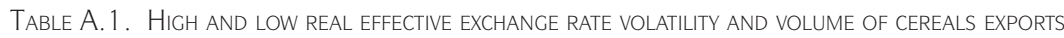

\begin{tabular}{|c|c|c|c|c|c|c|}
\hline \multirow{2}{*}{ Country } & \multicolumn{2}{|c|}{ Low REERV } & \multicolumn{2}{|c|}{ High REERV } & \multicolumn{2}{|c|}{ Volume of cereals exports } \\
\hline & V4 & V8 & V4 & V8 & Low & High \\
\hline \multicolumn{7}{|l|}{ Algeria (DZA) } \\
\hline \multicolumn{7}{|l|}{ Argentina (ARG) } \\
\hline \multicolumn{7}{|l|}{ Armenia (ARM) } \\
\hline \multicolumn{7}{|l|}{ Australia (AUS) } \\
\hline \multicolumn{7}{|l|}{ Austria (AUT) } \\
\hline \multicolumn{7}{|l|}{ Barbados (BRB) } \\
\hline \multicolumn{7}{|l|}{ Belgium (BEL) } \\
\hline \multicolumn{7}{|l|}{ Belize (BLZ) } \\
\hline \multicolumn{7}{|l|}{ Bolivia (BOL) } \\
\hline \multicolumn{7}{|l|}{ Brazil (BRA) } \\
\hline \multicolumn{7}{|l|}{ Bulgaria (BGR) } \\
\hline \multicolumn{7}{|l|}{ Burundi (BDI) } \\
\hline \multicolumn{7}{|l|}{ Cameroon (CMR) } \\
\hline \multicolumn{7}{|l|}{ Canada (CAN) } \\
\hline \multicolumn{7}{|l|}{ Chile (CHL) } \\
\hline \multicolumn{7}{|l|}{ China (CHN) } \\
\hline \multicolumn{7}{|l|}{ Colombia (COL) } \\
\hline \multicolumn{7}{|l|}{ Côte d'Ivoire (CIV) } \\
\hline \multicolumn{7}{|l|}{ Croatia (HRV) } \\
\hline \multicolumn{7}{|l|}{ Cyprus (CYP) } \\
\hline \multicolumn{7}{|l|}{ Denmark (DNK) } \\
\hline \multicolumn{7}{|l|}{ Dominican Republic (DOM) } \\
\hline \multicolumn{7}{|l|}{ Ecuador (ECU) } \\
\hline \multicolumn{7}{|l|}{ El Salvador (SLV) } \\
\hline \multicolumn{7}{|l|}{ Estonia (EST) } \\
\hline \multicolumn{7}{|l|}{ Finland (FIN) } \\
\hline France (FRA) & & & & & & \\
\hline Georgia (GEO) & & & & & & \\
\hline Germany (DEU) & & & & & & \\
\hline Greece (GRC) & & & & & & \\
\hline
\end{tabular}




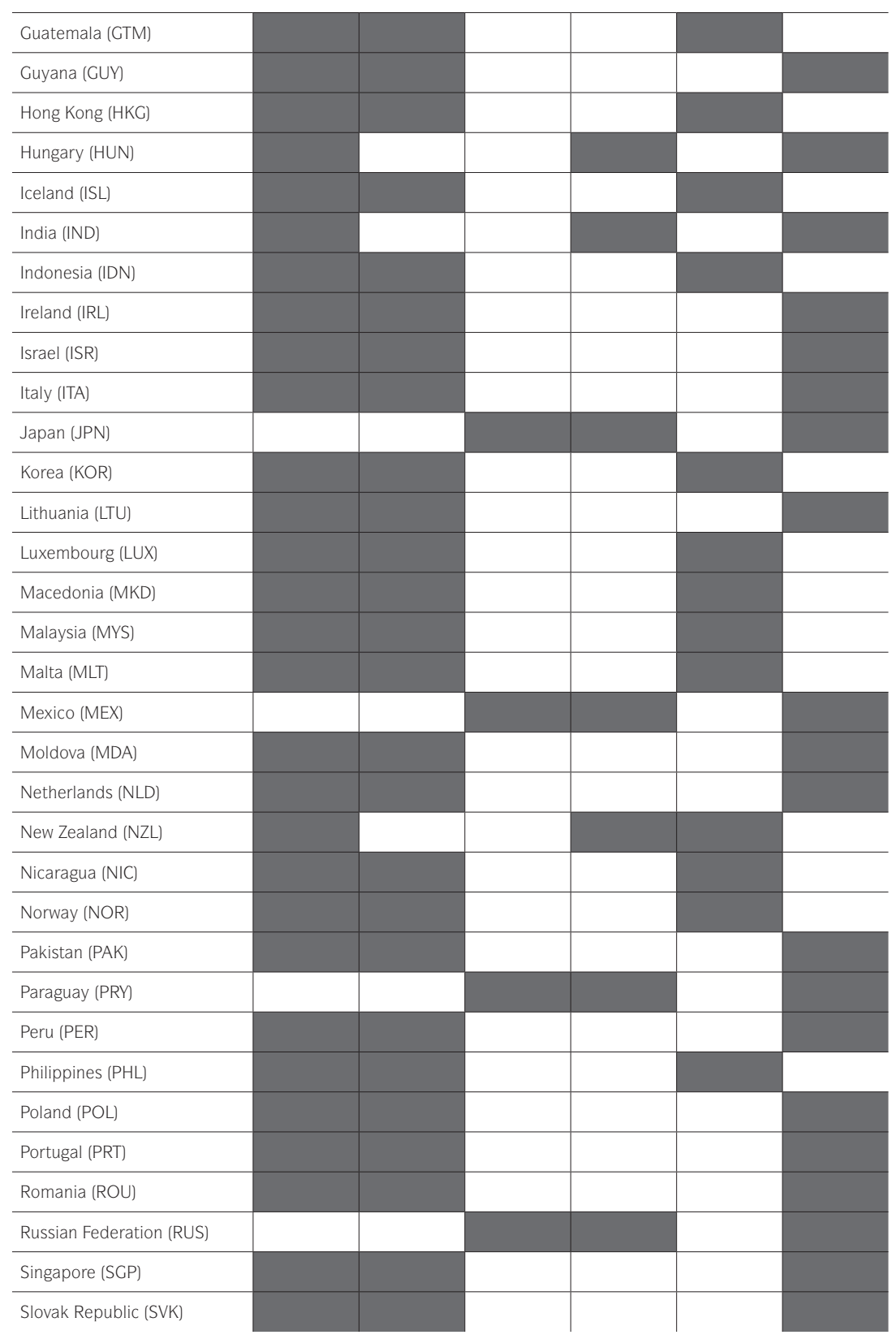




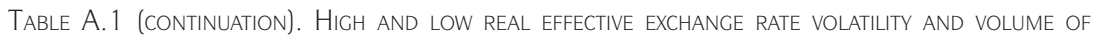
CEREALS EXPORTS

\begin{tabular}{|c|c|c|c|c|c|c|}
\hline \multirow{2}{*}{ Country } & \multicolumn{2}{|c|}{ Low REERV } & \multicolumn{2}{|c|}{ High REERV } & \multicolumn{2}{|c|}{ Volume of cereals exports } \\
\hline & V4 & V8 & V4 & V8 & Low & High \\
\hline \multicolumn{7}{|c|}{ South Africa (ZAF) } \\
\hline \multicolumn{7}{|l|}{ Spain (ESP) } \\
\hline \multicolumn{7}{|c|}{$\begin{array}{l}\text { St. Vincent and the } \\
\text { Grenadines (VCT) }\end{array}$} \\
\hline \multicolumn{7}{|l|}{ Sweden (SWE) } \\
\hline \multicolumn{7}{|c|}{ Switzerland (CHE) } \\
\hline \multicolumn{7}{|l|}{ Thailand (THA) } \\
\hline \multicolumn{7}{|l|}{ Togo (TGO) } \\
\hline \multicolumn{7}{|c|}{ United Arab Emirates (ARE) } \\
\hline \multicolumn{7}{|c|}{ United Kingdom (GBR) } \\
\hline \multicolumn{7}{|c|}{ United States (USA) } \\
\hline \multicolumn{7}{|l|}{ Uruguay (URY) } \\
\hline Zambia (ZMB) & & & & & & \\
\hline
\end{tabular}

Note: The grey share area indicates that the country is classified in this cluster group.

Source: Own elaboration.

TABle A.2. Panel unit-root test Results

\begin{tabular}{ccccc} 
Variable & \multicolumn{2}{c}{ Level } & \multicolumn{2}{c}{ First Difference } \\
\cline { 2 - 5 }$X$ & Adjusted statistic t* & Integration order & Adjusted statistic t* & Integration order \\
\cline { 2 - 4 } LV4 & $-1.128[0.130]$ & $\mathrm{I}(1)$ & $-11.950[0.000]$ & $\mathrm{I}(0)$ \\
HV4 & $-0.693[0.244]$ & $\mathrm{I}(1)$ & $-4.700[0.000]$ & $\mathrm{I}(0)$ \\
LV8 & $2.346[0.991]$ & $\mathrm{I}(1)$ & $-6.582[0.000]$ & $\mathrm{I}(0)$ \\
HV8 & $1.450[0.927]$ & $\mathrm{I}(1)$ & $-3.220[0.000]$ & $\mathrm{I}(0)$ \\
LX-V4 & $-0.079[0.468]$ & $\mathrm{I}(1)$ & $-7.645[0.000]$ & $\mathrm{I}(0)$ \\
HX-V4 & $-1.553[0.060]$ & $\mathrm{I}(1)$ & $-10.323[0.000]$ & $\mathrm{I}(0)$ \\
LX-V8 & $0.643[0.740]$ & $\mathrm{I}(1)$ & $-4.261[0.000]$ & $\mathrm{I}(0)$ \\
HX-V8 & $2.353[0.991]$ & $\mathrm{I}(1)$ & $-5.957[0.000]$ & $\mathrm{I}(0)$
\end{tabular}

Note: Levin-Lin-Chu (LLC) unit root test for variables in levels; null hypothesis: panels contain the integrated series. Im, Pesaran and Shin (IPS) unit root test for variables in first difference. Level of significance of the test 95\%. In [...] p-value. The number of delays was selected by the Akaike criterion, max. delays $=10$. The variables were considered in logarithm. And cross-sectional dependence was eliminated. Sample: 2010/01 - 2016/12. The cereal export series gaps avoid running panel unit root test; therefore, we assume that cereal export series behave in the panel as integrate of first order, I(1).

Source: Own elaboration. 
TABLE A.3. Adf UNIT ROOT TEST: UNIVARIATE ANALYSIS

\begin{tabular}{ccccc} 
Variable & \multicolumn{2}{c}{ Level } & \multicolumn{2}{c}{ First Difference } \\
\cline { 2 - 5 } & Statistical value & Integration order & Statistical value & Integration order \\
\hline $\mathrm{M}^{*}$ & $-2.743^{*}$ & $\mathrm{I}(1)$ & $-8.186^{* * *}$ & $\mathrm{I}(0)$ \\
& $(11$ lags $)$ & & $(10$ lags $)$ & \\
$\mathrm{P}$ & -2.018 & $\mathrm{I}(1)$ & $-5.674^{* * *}$ & $\mathrm{I}(0)$ \\
& $(1$ lags $)$ & & $(0$ lags $)$ & \\
$\mathrm{P}^{*}$ & -1.252 & $\mathrm{I}(1)$ & $-6.211^{* * *}$ & $\mathrm{I}(0)$ \\
& $(1$ lags $)$ & & $(0$ lags $)$ & \\
\hline
\end{tabular}

Note: Augmented Dickey-Fuller (ADF). Null hypothesis: there is a unit root. The number of delays was determined according to the Akaike criterion (maxlag $=11$ ). The ADF model was specified with a constant. The variables were considered in logarithm. Level of significance: *: $10 \%,{ }^{* *}: 5 \%,{ }^{* * *}: 1 \%$.

Source: Own elaboration. 
